DOI: https://doi.org/10.34069/AI/2021.37.01.16

\title{
Asian financial development: the rise of a new financial system
}

\section{Финансовое развитие в Азии: становление новой финансовой системы}

Received: January 15, 2021

Accepted: March 5, 2021

\author{
Written by: \\ Elnur T. Mekhdiev ${ }^{52}$ \\ https://orcid.org/0000-0001-6248-6673 \\ Zulfiya M. Bikmetova ${ }^{53}$ \\ https://orcid.org/0000-0001-5025-1826 \\ Elvira N. Iamalova ${ }^{54}$ \\ https://orcid.org/0000-0003-2588-1871 \\ Oksana N. Ignatieva $\mathbf{5}^{55}$ \\ https://orcid.org/0000-0002-9374-7378 \\ Aygul F. Samigullina ${ }^{56}$ \\ https://orcid.org/0000-0001-9026-7259
}

\begin{abstract}
Today, the global financial system is inefficient in bridging the gap between the developed and developing countries. The dynamically developing countries, such as Asian states, are not satisfied with modern international financial institutions and are actively involved in regional integration, creating new international financial institutions. The newly formed financial institutions contribute to the formation of a different system of financial relations in Asia, which, in turn, is being transformed into the Asian financial system. These trends cannot avoid the impact of the global imbalances. The object of the article is to prove the efficiency of the Asian financial institutions in fighting global imbalances in the region. The major task of these institutions is not the substitution of the current global mechanisms, but their assistance and helping them in solving the global problems on the regional level. The major results include the proof that the developing economies in Asia are more consolidated and capable of conducting a single economic strategy in the long run and the proof of the higher efficiency of Asian financial institutions and their single geo-economic strategy in the long run; this suggests that a new Asian financial system is being built.
\end{abstract}

\begin{abstract}
Аннотация
Сегодня мировая финансовая система неэффективна в преодолении разрыва между развитыми и развивающимися странами. Динамично развивающиеся страны, такие как государства Азии, не удовлетворены современными международными финансовыми институтами и активно участвуют в региональной интеграции, создавая новые международные финансовые институты. Вновь образованные финансовые институты способствуют формированию иной системы финансовых отношений в Азии, которая, в свою очередь, трансформируется в азиатскую финансовую систему. Эти тенденции не могут избежать воздействия глобальных дисбалансов. В статье показано, что создание этих институтов в Азии связано с фундаментальными недостатками мировой финансовой системы, и новые международные финансовые институты могут эффективно справляться с этими недостатками. Основной задачей статьи было объединить новые финансовые тенденции в Азии и структурировать их в систему взаимосвязанных процессов, чтобы доказать появление азиатской финансовой системы. Авторы показали, что
\end{abstract}

\footnotetext{
${ }^{\mathbf{5 2}}$ Research fellow, Center for Analysis, Risk Management and Internal Control in Digital Space, Financial University under the Government of the Russian Federation, Moscow, Russia.

${ }^{53}$ Assistant professor. Bashkir State University, Ufa, Russia.

${ }^{54}$ Professor. Bashkir State University, Ufa, Russia.

55 Assistant professor. Bashkir State University, Ufa, Russia.

${ }^{56}$ Assistant professor. Bashkir State University, Ufa, Russia.
} 
Key Words: Asia, global financial system, international financial institutions, fundamental flaws.

\section{Introduction}

The development of the global financial system today is uneven and undermined by numerous flaws, which are expressed in the inability of modern institutions to prevent a crisis and balance the world economy in such a way that it does not face regular depressions. In addition, the modern global financial system cannot offer ways to close the gap between the developed and developing economies. These factors lead to the creation of new international financial institutions that provide alternatives to modern financial regulation. Most of these alternatives are in Asia, further, they are closely related to each other.

Fundamental differences in approaches to the regulation of global finances by the developed and developing countries suggest that initiatives aimed at changing the current situation will emerge in the developing countries, especially in financial institutions, including several developing economies with similar development characteristics. This situation is observed in Asia, so the initiative to transform the economy will arise from Asia.

The hypothesis of our research is based on these trends - Asian international financial institutions unite Asian countries in a single financial system, which has many differences from the modern global financial system and is more efficient in overcoming its flaws. To prove this, the authors use dispersion analysis based on indicators characterizing the main flaws of the global financial system. The authors put forward three main directions for the development of cooperation between Asian international financial institutions and the development of the Asian financial system as a whole. развивающиеся экономики в Азии более консолидированы и способны проводить единую экономическую стратегию в долгосрочной перспективе. Основной вклад статьи - доказательство более высокой эффективности азиатских финансовых институтов и их единой геоэкономической стратегии в долгосрочной перспективе; это говорит о том, что строится новая азиатская финансовая система.

$\begin{array}{lcr}\text { Ключевые слова: } & \text { Азия, мировая } \\ \text { финансовая } & \text { система, } & \text { международные } \\ \text { финансовые институты, } & \text { фундаментальные } \\ \text { недостатки. } & \end{array}$

\section{Literature review}

First of all, we suggest concretizing the theoretical framework. The global financial system is a highly debated term, especially in the context of globalization (Schmidt and Hryckiewicz, 2006). The authors adhere to the definition of the global financial system as those financial institutions and regulations that operate at the international level, as opposed to those that operate at the national or regional level. Key players are global institutions such as the International Monetary Fund (IMF) and the World Bank, national agencies and government departments, such as central banks and ministries of finance, as well as private institutions operating globally, such as banks and hedge funds (James, and Patomäki, 2007). The discussed hereinafter global imbalances are quite often referred as the failures of global financial system (Buckley \& Arner, 2011), which cause crises, but this attitude is too narrow, as the global financial system includes, but has little influence of global financial regulation, so these failures refer to the global financial regulation too. This point of view is expressed in (Jones \& Knaack, 2019), where the failures are named as the shortcomings. As a result, in order to summarize these approaches, the term "fundamental flaws" is used in the article. This term arises from global imbalances, put forward in (Obstfeld \& Rogofh, 2009), where these imbalances were described, but not substantialized.

The literature on integration processes in Asia is extensive (over 6800 articles in the Scopus database). The authors have singled out several important blocks. The first block includes studies, especially by Stiglitz (Basu et al. 2019; Blanchard, 2012; Stiglitz, 2015), in the field of reforming the global financial system. According to them, the global financial system needs 
reforms, its mechanisms are outdated and are used by the most powerful economic actors to gain extra profits. These studies also provided an analysis of the imbalances of the global financial system, which has been put in the basis of identifying the fundamental flaws of the global financial system within our research. Based on (Biswas, 2018), the authors have discussed emerging economies and their role in reforming the global financial system (World Bank, 2019), provided a link between global financial regulation and regional international financial institutions. Previous studies provided a strong basis for this article, however, the situation with global imbalances is not stable, and this study offers a new approach to their research in the context of developing Asian economies.

The second block refers to integration processes in Asia. It includes numerous works on regional integration, which describes new opportunities for Asian developing countries in the current state of abundance of development institutions in the Asian region (Codeço, 2018; Xu, Ren, and $\mathrm{Wu}, 2019$ ), provided a brief overview of the situation in Asia regarding institutionalization of integration. (Bird, et al. 2020), gave a comprehensive analysis of the Belt and Road Initiative as the basis for further development of the Asian financial system. This study focuses on interactions between institutions in Asia, their systematic review, whereas previous studies focused on assessing the efficiency and role of an individual institution. The Asian financial system was not the subject of the research.

The third block is closest in its scope to this research. It includes the studies on the influence of regional financial institutions on regional economies (Ozili, 2020) contributed to the study of the initial goals of Asian financial institutions, allowing to conclude that their efficiency largely depends on the economic response of regional economies to their actions (especially in the field of social development). (Jędrzejowska, 2020), contributed to understanding the transformation of financial government in Asia; although the author did not put forward the idea of a new Asian financial system, but proved the massive changes in financial regulation, provoked by changes in financial flows (Taghizadeh-Hesary et al, 2019), provided the analysis of financial integration outcomes for Asian countries and highlighted that Asian countries benefit significantly from the new financial institutions in Asia. These studies do not have the necessary predictive potential, as they mainly focus on short-term changes or systematic potential for change, while this article puts forward specific scenarios.

Despite the fact that the literature is vast, it did not explore the development potential of Asian institutions from the point of view of the fundamental flaws of the global financial system.

Therefore, this article contributes to substantializing the Asian financial system through international financial institutions that are involved in building the Asian financial system and are more efficient than the existing ones. These institutions function in accordance with a single strategy that is implicitly provided for by the Asian financial system and the major economies of the region.

\section{Methodology}

First, the authors give a concrete vision of the key terms used in this article. International financial institutions (IFI) are represented by regional and global development banks, investment mechanisms (for example, the Silk Road Investment Fund) and supra-regional projects (such as the Belt and Road Initiative or CETA), which all have a financial component in one way or another. Trade agreements, such as ASEAN or numerous free trade agreements (FTAs), have a significant impact on the development of the global financial system, but are not included in the IFI within this research.

Further, the authors prove that the modern global financial system is not efficient enough, therefore, its institutions that existed before the globalization of developing countries should be replaced by new institutions. An example of Asia, as one of the fastest developing regions, is the most representative. Thus, we:

1) give the fundamental flaws of the global financial system arising from its inefficient institutions;

2) prove the high efficiency of the new development institutions of Asia in solving the economic problems of Asian countries;

3) demonstrate the systematic creation of an alternative financial system in Asia.

To prove the high efficiency of Asian international financial institutions, the authors conducted a dispersion analysis of economic data, referring to the key indicators characterizing the flaws of the global financial system. The methodology of dispersion analysis 
is as follows (analytical dispersion characteristic - ADC) (1):

$$
A D C=\sqrt{\frac{\sum\left(x_{n}-\bar{x}\right)^{2}}{(n-1)}} / \frac{\sum\left(x_{1}, x_{2} \ldots x_{n}\right)}{n}
$$

where $\mathrm{n}$ is the number of countries included in the equation (within this research - 10 developed countries, 10 most dynamically developing economies, consequently $n=10$ for the developed and developing countries dispersion value and 20 for the total dispersion value), $\mathrm{x}(\mathrm{n})$ - the value of a parameter for a specific country, ${ }^{-} \mathrm{x}$ is the average value for the specific year for all countries.

The countries selected for analysis are divided into two groups, the first includes the developed countries: France, Germany, Greece, Iceland, Ireland, Italy, the Great Britain, the United States, Japan and Singapore. The second includes the most dynamically developing economies (in accordance with the average GDP growth rate since 2000): China, the Republic of Korea, Mongolia, Thailand, Vietnam, Indonesia, India, Brazil, Malaysia and South Africa. Such a choice of the studied countries is explained by their rapidly growing influence and active participation in integration initiatives and the formation of IFI. The developed countries are chosen due to their high influence on the modern global financial architecture.

The higher the ADC, the more unequal is the distribution of value between the countries of the group. The high dispersion of value leads to the different goals of the states, as the countries follow their own strategies to gain more and to conquer a higher position, as the differences between them are high and allow to gain significant profits is moving up in the "list". The integration of such countries into a sustainable structure in order to overcome fundamental flaws is very difficult, while in those with low dispersion, these problems are easier to overcome through compromise.

The proof of lower ADC in Asia will allow to make conclusion, that the Asian economies are not just forming short-run alliances, but are forming a new financial architecture in the region.

The comparative study of the major financial indicators and their dispersion (deviation from the median) between the developing Asian economies, building the regional financial architecture and the countries, which have actively participated in the creation of the modern one, provides basis for the recommendation given in the article on the better development of the Asian economies in the conditions of the Asian financial architecture emergence.

\section{Results and discussion}

A. Fundamental flaws of the global financial system

The modern global financial system is far from perfect functioning. The global financial crisis of 2008-2010 and the European debt crisis of 2012 demonstrated that the financial regulation system used today cannot withstand modern challenges and properly respond to them. The same idea was expressed by Stiglitz (Serra, and Stiglitz, 2008; Stiglitz, 2010), at the beginning of the century, after many authors discussed it, but there is no consensus on this issue.

The global financial system functions on the basis of rules developed immediately after the World War II and the rules of the Washington Consensus (Agarwal, 2018), which are not specific and comprise recommendations on the strategic goals of the economy.

The traditional division of countries according to their level of development into developed, developing economies and economies in transition is no longer sufficient. More sophisticated divisions (for example, see (Taleb, 2010), do not reflect development potential and are more likely to be statistical in nature. The authors propose to introduce a new term - the most dynamically developing economies, which includes countries that have high rates of economic growth and at the same time high investment potential (host significant amounts of investments in the region where they are situated), and are highly integrated into the regional institutional infrastructure (actively involved in the creation, financing and promotion of regional IFI). These countries can compete with the developed countries, which are interested in maintaining their leading position and can use the flaws of the global financial system to achieve this goal (Davidson, 2004; World Bank, 2019).

The most dynamically developing economies pose a problem for the modern global financial system, since they are not represented in its institutions at a level corresponding to their position in the global economy (Obstfeld, 2009; 
Orastean, 2016; Timmis, 2018), their ambitions are not satisfied, therefore, to develop at a faster pace, they are looking for ways to build a fairer and more effective global financial system. This can be achieved by introducing a new IFI aimed at mitigating the consequences of fundamental flaws of the global financial system (as follows from the above, these flaws are one of the key reasons why the developing countries strive to create new institutions of global financial regulation).
The flaws of global financial regulation, which cause deep concern among the developing countries, can be deduced from data on the creation of new financial institutions in the world. The authors extracted a list of financial institutions used in (Xu, Ren, and Wu, 2019), and examined the initiatives of international development banks (IDB) creation over time. The results are presented in Table 1 .

Table 1.

Development banks creation: distribution over time.

\begin{tabular}{|c|c|c|c|c|c|c|c|c|}
\hline Period & 1940-49 & 1950-59 & $1960-69$ & $\begin{array}{l}1970-79 \\
\end{array}$ & 1980-89 & 1990-99 & $2000-09$ & 2010-19 \\
\hline $\begin{array}{l}\text { Total number of } \\
\text { created IDB }\end{array}$ & 1 & 2 & 5 & 7 & 2 & 6 & 3 & 3 \\
\hline $\begin{array}{l}\text { Number of IDB } \\
\text { created by the } \\
\text { developing } \\
\text { countries' initiative }\end{array}$ & 0 & 0 & 3 & 5 & 1 & 3 & 3 & 3 \\
\hline $\begin{array}{l}\text { Share of IDB } \\
\text { created by the } \\
\text { developing } \\
\text { countries' initiatives }\end{array}$ & 0 & 0 & $60 \%$ & $71 \%$ & $50 \%$ & $50 \%$ & $100 \%$ & $100 \%$ \\
\hline
\end{tabular}

Source: created by the authors.

The dynamics of creating development banks shows that the developing economies have been searching for new sources of capital and trying to attract investment over the past 20 years. This leads to the conclusion that the first fundamental flaw of the global financial system is the mismatch of investment flows between the developed and developing economies.

An analysis of the data from (RTAs Database, 2020), allows to conclude that the pace of creating FTAs is slowing down, but most of them (over $80 \%$ of all FTAs created after 2000) were initiated by the developing countries. This leads to another conclusion about the flaws of the global financial system: the inability to effectively regulate trade and, consequently, the current account balance.

This, in turn, leads to debt problems of the countries. Today, the IMF is one of the leading IFI in the field of debt management, but its resources are far from enough to ensure a balance in the global financial system (Table 2).

Table 2.

Share of IMF resources compared to the global level of debt.

\begin{tabular}{|c|c|c|c|c|c|c|c|c|c|c|}
\hline Year & 2009 & 2010 & 2011 & 2012 & 2013 & 2014 & 2015 & 2016 & 2017 & 2018 \\
\hline $\begin{array}{l}\text { Total debt (USD } \\
\text { bln) }\end{array}$ & 9,696 & 11,403 & 13,262 & 14,715 & 16,567 & 17,709 & 16,854 & 17,453 & 19,210 & 20,209 \\
\hline SDR rate to USD & 0.638 & 0.652 & 0.653 & 0.651 & 0.649 & 0.69 & 0.721 & 0.744 & 0.702 & 0.719 \\
\hline $\begin{array}{l}\text { IMF resources } \\
\text { (SDR mln) }\end{array}$ & 374.3 & 405.5 & 540.5 & 518.5 & 543.8 & 505.8 & 541.5 & 895.1 & 703 & 722 \\
\hline $\begin{array}{l}\text { Share of IMF } \\
\text { resources in } \\
\text { global debt }(\%)\end{array}$ & 0.0061 & 0.0055 & 0.0062 & 0.0054 & 0.0051 & 0.0041 & 0.0045 & 0.0069 & 0.0005 & 0.0050 \\
\hline
\end{tabular}

Source: calculated by the authors on the basis of IMF financial data (IMF, 2019; IMF, 2020).

Hence, the third flaw of the global financial system is the inability to support countries in case of high debt and crisis.

The next issue arises from the level of debt and the Triffin paradox (Campanella, 2009;
Ikenberry, 2009) - the unipolarity of the monetary system. The US dollar is the key currency in the world (Lee, 2019), while the developed countries can manipulate their currencies exchange rate in order to make financial profits for their companies 
(Veselovsky, 2017). Currency wars arise as a result of these actions and make the financial system unstable, and the development of the economies of the whole world uneven.

Given the digitalization and globalization, another, the most recent, issue should be mentioned, which is the uneven distribution of non-material assets and human capital (Ngwu, 2018; Ray, and Dutta, 2014), that, in turn, leads to asymmetric information distribution (in particular, in the financial sector). This is part of another flaw of the global financial system - the unreasonably high transaction costs leading to information asymmetry.

The identified flaws of the global financial system lead to the formation of risks, which, in turn, are the key contributors to the beginning of economic crises and slowdown in GDP growth.

All in all, inequality in the distribution of power and financial resources in one country (Stiglitz, 2013), leads to a decrease in performance of the country economy as a whole. On a global scale, inequality causes crises, leading to the devastation of economies both developing (to a lesser extent) and developed (to a greater extent due to higher levels of globalization and worse consequences of the transfer of crisis).

B. Trends in the consolidation of the Asian region and the formation of the Asian financial system

The choice of the role of IFI lies more in the field of its capabilities than in the will of its creators (Engen, L., and Prizzon, A. 2018). After 2000, Asian countries created a number of important international financial institutions, such as the Asian Infrastructure Investment Bank (AIIB), the Belt and Road Initiative (BRI), the BRICS New Development Bank (NDB), the Silk Road Investment Fund, the Comprehensive Economic Partnership and several less important initiatives.

As a result, Asia is one of the most intensive integration regions in the world, while Asian IFI form a "noodle bowl". At the same time, some of them (mentioned above) form a logical system of institutions interconnected through financial and economic interactions and similar task of regional development.

To prove the high efficiency of these mechanisms, the authors have conducted dispersion analysis of economic indicators presented in Fig. 1.
Fig. 1 shows the increase in the deviation in GDP of the most dynamically developing countries since 2000, while for the developed economies the deviation of GDP remains nearly the same.

Since 2010, the average deviation of GDP has become lower than the deviation of the GDP of the developing countries, which means the following: with the active introduction of Asian IFI in the $2000 \mathrm{~s}$, some of the most dynamically developing countries have benefited significantly. From the same GDP growth of other studied developing countries, it can be concluded that there has been a change in the GDP growth of the developed or least developed countries' (LDCs) economies. At the same time, the LDCs of Asia entered a new period of renaissance in economic development, therefore, the rise of deviation in GDP growth was achieved due to the decline in GDP of the developed economies.

Exchange rate deviation remains high, but does not correlate with the dynamics of GDP deviation. It remains stable for the developing economies and falls slightly for the developed countries, while the average exchange rate deviation is significantly higher than both of the previously described deviations. This leads to the conclusion that the currencies of Asian countries are less interconnected than the currencies of the developed countries, while both currency groups are weakly interconnected.

The dynamics of deviation of the developed countries reserves, which decreased significantly after the global financial crisis of 2008, along with the stable dynamics of deviation of the developing countries reserves, allows to conclude that the developing countries reserves are distributed more unevenly, but did not suffer as much from the global financial crisis.

The constant decline in the deviation of the developing countries public debt with an increase in the same indicator for developed countries after 2008 proves that the developed countries, in competition with the economies of the most dynamically developing countries, consolidate them and contribute to the creation of a more stable system of relations between the developing economies and their more active cooperation in creating IFI.

The dynamics of the dispersion of the foreign direct investment (FDI) inward flow demonstrates the higher stability of the economies of the most dynamically developing countries, while the dispersion of the FDI 


\section{AMAZOND周 \\ 1nvestiga}

outward flow shows the rapid growth of investment capabilities of some of these countries, which can be used in common development mechanisms, for example, in the mechanisms of institutional development, such as development banks.

The rise in the dispersion of patent applications by the developing countries, along with a constant fall in this indicator for the developed countries, leads to the conclusion that the developing countries face unequal conditions in the development of non-material assets, while the developed countries consolidated through IFI managed to create mechanisms for the distribution of intellectual property and develop in this area in a more balanced way than the developing countries.

All the mentioned trends (except the one related to the sphere of patents) are united by one important fact - all of them prove the consolidation of the Asian region, which in some aspects is hindered by the consolidation of the developed economies (for example, for intellectual property, this is confirmed by the dynamics of patent applications dispersion, and for monetary policy - by the exchange rates). A large number of IFI in Asia, consolidation of the region and high development pace demonstrate the efficiency of the IFI in Asia.

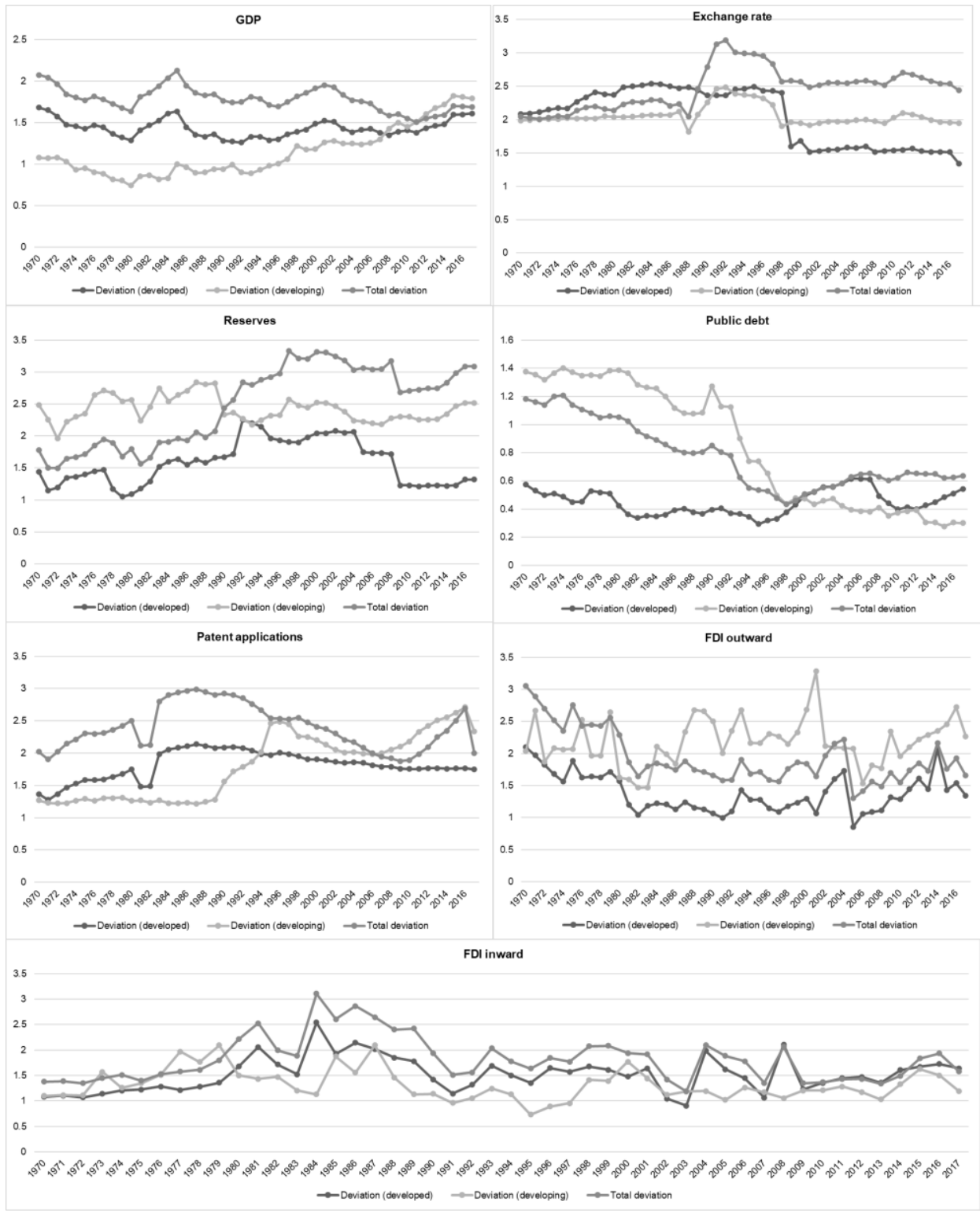

Fig. 1. Results of the dispersion analysis.

Source: created by the authors. 
C. The role of Asia in creating a new financial system

Despite the fact that many dynamically developing economies are not Asian, Asian financial institutions play the major role in creating a new financial system. As demonstrated above, Asian financial institutions play a consolidating role for Asian economies. This consolidation brings numerous benefits to Asian economies, for example, a single course of economic development allows to more effectively support the region's LDCs at the national level.

Another important function of Asian financial institutions and their key difference from other IFI is their search for highly efficient measures taken to develop the regional economies. This thesis arises from the following important points: first of all, AIIB and NDB reduce operating costs. Their personnel are much smaller - 186 and less than 250, respectively, compared with 3,000 and 10,000 for the European Bank for Reconstruction and Development and the World Bank Group (AIIB, 2019; Crunchbase, 2020; EBRD, 2020; World Bank, 2020). Secondly, AIIB and NDB projects are more practical - the share of consulting services in their project portfolio is less than $10 \%$ (AIIB, 2020., NDB, 2020). As a result, their actions allow to attract more financial resources to the LDCs at lower cost, since consulting projects work better for the developed countries with a clear relationship between economic processes, while the institutional structure of the LDCs is weak and economic laws does not work as they should.

The overall higher efficiency of AIIB and NDB is proved by both their actions and the institutional structure (Guliev et al, 2019), (while ADB seeks ways to improve efficiency (O'Keeffe et al, 2017). Furthermore, when speaking of BRI - the Asian financial system basic project, the pace of its spread across the countries of the Maritime Silk Road Belt (Chan, 2018; Merics, 2018), is fast, and the investment in their economies is massive, creating a synergistic effect for the project as a whole. As a result, BRI has come to a new dimension - an investment megaproject, which was originally aimed at stimulating trade.

Comparing BRI with CETA, for example, allows to draw the following conclusions: BRI has lower institutional quality but greater flexibility in solving infrastructure and energy issues; CETA is clearly a more trade-oriented agreement, while BRI plays a significant role in trade growth, but has an equally important role in the development of investment cooperation in Asia and beyond; CETA has clear geographical boundaries that are difficult to expand, while BRI is constantly expanding and creating new opportunities for its members; CETA provides effective bilateral cooperation mechanisms, BRI provides more opportunities for multilateral cooperation, but in the field of bilateral cooperation there is an imbalance in the role of China in the project (China Power, 2019; L 11/23, 2017; Hubner, et al. 2016; Prodi and Fardella, 2018). As a result, BRI is more flexible and more effectively adapts to the changing global conditions, thus showing the key difference of the Asian financial system - its flexibility and adaptability.

At the same time, the Asian financial system has to interact with IFI that do not possess the same qualities as the Asian IFI. In addition, this interaction is necessary for a non-isolation strategy of Asian countries. Intermediary institutions such as ASEAN, the Shanghai Cooperation Organization (SCO) and the Eurasian Development Bank (EDB) play an important role in the Asian financial system. ASEAN stimulates trade in the Asia-Pacific region, one of the most dynamically developing regions of Asia (Litsareva, 2017), at the same time, it plays the role of a mechanism for unifying the institutional rules in Asia. The ASEAN Charter promotes a liberal attitude towards trade and development without strict regulation of both areas, which leads to the implementation of the "ASEAN way" (Cho and Kurtz, 2018), in the Asian financial system as a whole. SCO is a security dimension of cooperation in Asia: it links the countries of Central Asia that are least integrated into the framework of Asian institutions and promotes security. This connection is weak - security issues are not directly related to the Asian financial system, but the SCO Bank's creation plans (Gabuyev, 2015; Reuters, 2016), allow to conclude that SCO is another organization contributing to the functioning of the Asian financial system as a whole, including the Central Asia region.

EDB is a very important institution for the Asian financial system. Under the current unstable situation on the global market, the trade war unleashed by the United States against China and the new coronavirus pandemic, isolation trends in the Asian region are intensifying. EDB plays a vital role in preventing the collapse of the Asian financial system, because it offers a weak functional connection - it works in the EAEU and Central Asia and can be used as an 
intermediary bank institution for Asian financial resources and for Asia-Europe financial flow. The same can be said about the Asian Development Bank, but due to its main shareholders, and because it is tending more to the World Bank Group structure and functioning, than to the new IFI of Asia, it has little or no influence on the Asian financial system's overcoming isolation (Guttal, 2005; Jakupec, and Kelly, 2015).

As a result, a key role in the process of creating the Asian financial system belongs to several Asian IFI, which proved to be more efficient in crisis situations and in combating the fundamental flaws of the global financial system at the regional level. Asian countries do not aim at creating a new global financial system, their role is to reform modern institutions, they do not have sufficient power or motive to create a new financial system at the global level. At the same time, the transformation and cooperation of regional IFI allows to predict the formation of a specific sector of the global financial system the Asian financial system, the spread of which at the global level is unlikely due to institutional specifics and the need for economic conditions that are present mainly in Asia today (as described in (ESCAP, 2018; Howe and Park, 2017), and which are difficult to copy and repeat.

\section{Possible scenarios}

The above results are the subject of active discussion, since they cannot be indicated either as a reason for better economic development or as its consequences. The authors have demonstrated how these features of Asian IFI contribute to economic development, but the prospects for the Asian financial system as a whole depend on the course of the Asian financial institutions. There are three main courses that arise from current trends: 1) maintaining the status quo, 2) the regional development and the formation of the Asian financial system as part of the global financial system, and 3) counteracting the global financial system, which is likely to lead to the isolation of the Asian IFI.

The first scenario is the least promising for Asian IFI; they do not risk, but the development of the region does not acquire new drivers, and Asian countries do not receive additional support from specific points and higher efficiency of the Asian IFI. This track is most beneficial for the developed economies, as they preserve their dominance in the global financial system; the gap between the economic indices of the developed and developing economies grows, as is the gap between Asian economies, since Asian financial institutions will not be able to pursue a consolidating strategy due to fall in their efficiency (Saggu, and Anukoonwattaka, 2015), for China, as an example). As a result, Asian countries lose the opportunity to create a second center of power in the world. This scenario does not require any action from Asian IFI and Asian countries (Riedel, 2011).

The second scenario is more risky: Asian IFI cooperate and develop the existing operational and institutional models, this leads to the formation of a part of the global financial system, which operates differently. This part should be integrated into the global financial system, or at least into its institutions; this, in turn, will lead to reform in the global financial system, since the need for cooperation with Asian IFI at the same level of efficiency requires the transformation of the main institutions of the global financial system. This scenario requires Asian IFI to narrow the gap between regional economies through higher investments. The main options for attracting these investments are as follows:

1) Attracting investments from the developed economies - the EU, Japan and the United States. This investment flow is limited due to the difficult relationship between China as one of the main recipients of investments in Asia and the developed countries led by the United States (Bungenberg, and Hazarika, 2017; Sung, \& Uk, 2008).

2) Attracting investments from the developing countries - this investment flow is limited in volume, and a significant amount of such investments is portfolio investment.

3) Attracting investments from various groups of countries using instruments of non-Asian IFI, such as EDB (Vinokurov, et al. 2019), for example). At the moment, the scope of such instruments is not wide, and the flow of investment is very limited.

These options should be used together, since all of them today tend to be limited by geoeconomic factors.

The third scenario involves isolation of the Asian financial system due to the confrontation between the developed and developing economies. This scenario is the most devastating for the global financial system and for Asian economies. At the same time, it allows to quickly build a sustainable regional financial system. The 
effectiveness of this scenario is doubtful for all parties, but in the case of higher tensions between China and the United States, it has a greater chance of implementation. In the case of this scenario, Asian IFI have two main options: retreat and accept the status quo scenario or continue the confrontation, trying to minimize risks. For this, Asian IFI should:

1) Develop and apply a reservation system that will allow them to operate in the case of low capital inflows and high outflows (for example, reserve a fixed percentage of each financial project investment initiated by them).

2) Develop an alternative system of access to the global capital markets; the basis of such a system today is the EDB.

3) Introduce a long-term risk management system that will allow evaluating the portfolio of Asian IFI in terms of their ability to ensure sustainable growth of the region as a whole.

All three scenarios are the most likely and include many additional scenarios that are not considered in this article. In general, Asian IFI are building the units of the new financial system, but the path of its development at the moment strongly depends on the position of the leading countries of the region (China, India, ASEAN countries) on their future and on the response to their actions from the developed economies. In addition, unexpected events can significantly affect the balance (Taleb, 2010), for example, the situation with COVID-2019 or natural disasters.

\section{Conclusions}

The global financial system is not balanced. It functions with many flaws. The main ones are: the mismatch of investment flows between the developed and developing countries, the inability to effectively regulate trade and, therefore, the current account balance, the inability to provide support to countries in case of high debt and crises, the unipolarity of the monetary system and the information asymmetry. These fundamental flaws lead to the need to transform the global financial system. One of the modern alternatives that is being created is the Asian financial system.

Asian IFI have several differences from other IFI, which allows them to narrow the gap between the most dynamically developing economies and Asian LDCs. This leads to faster and more stable development of the region and the creation of a system of IFI, united by their positive impact on the fundamental flaws of the global financial system, at least in the Asian region.

The Asian financial system allows the countries of the region to form close economic ties, cooperate with lower transaction costs, which, in turn, requires a change of roles on the global arena. This does not satisfy the developed economies, which counteract the formation of the Asian financial system. This counteraction leads Asian IFI to follow one of the scenarios: maintaining the status quo, a slow and steady reform of the global financial system through the integration of the Asian financial system as a sector of the global one or isolation of the Asian financial system.

At present, the second scenario seems most likely, but in the current circumstances of massive efforts to isolate China and other Asian economies, the third scenario is likely to become a reality.

\section{Reference}

Agarwal, P. (2018). Washington Consensus. Intelligent Economist. Retrieved from https://www.intelligenteconomist.com/washingt on-consensus/

AIIB. (2019). How we're developing. Retrieved from https://www.aiib.org/en/newsevents/annual-report/2018/how-we-are-

developing/index.html

AIIB. (2020). Approved Projects. Retrieved from https://www.aiib.org/en/projects/approved/index .html

Basu, K., Sepúlveda, C. P., and Rosenblatt, D. (Eds.). (2019). The state of economics, the state of the world. Cambridge, MA: MIT Press.

Bird, J., Lebrand, M., and Venables, A. J. (2020). The Belt and Road Initiative: Reshaping economic geography in Central Asia? Journal of Development Economics, 144, 102441. doi: 10.1016/j.jdeveco.2020.102441

Biswas, R. (2018). Emerging Markets Megatrends. Cham: Springer International Publishing. doi: 10.1007/978-3-319-78123-5

Blanchard, O., Romer, D., Spence, M., and Stiglitz, J. E. (Eds.). (2012). In the wake of the crisis: Leading economists reassess economic policy. Cambridge, Mass: MIT Press.

Buckley, R., \& Arner, D. (2011). From Crisis to Crisis: The Global Financial System and Regulatory Failure. International banking and finance law series. Volume 14. Walters Kluwer. Hong Kong.

Bungenberg, M., and Hazarika, A. (2017). The European Union's trade and investment policy in 
Asia: New challenges and opportunities in a changing global environment - or: following individual roadmaps. Asia Europe Journal, 15(4), 377-397. doi: 10.1007/s10308-017-0485-2 Campanella, E. (2009). The Triffin Dilemma Again (Economics Discussion Paper No. 2009-46). Retrieved from https://dx.doi.org/10.2139/ssrn.1726749

Chan, M. H. T. (2018). The Belt and Road Initiative - the New Silk Road: A research agenda. Journal of Contemporary East Asia Studies, $\quad 7(2), \quad 104-123$. doi: 10.1080/24761028.2019.1580407

China Power. (2019). How will the Belt and Road Initiative advance China's interests? Retrieved from https://chinapower.csis.org/china-belt-and-roadinitiative/

Cho, S., and Kurtz, J. (2018). Legalizing the ASEAN Way: Adapting and Reimagining the ASEAN Investment Regime. The American Journal of Comparative Law, 66(2), 233-266. doi: 10.1093/ajcl/avy026

Codeço, R. R. (2018). The Asian Infrastructure Investment Bank, the New Development Bank and the Internationalisation of the Renminbi (RMB)-The New International Financial Institutions as Part of the Chinese Strategy to Build Up an International Reserve Currency. Contemporary Chinese Political Economy and Strategic Relations, 4(3), 821-868.

Crunchbase. (2020). New Development Bank. Retrieved from https://www.crunchbase.com/organization/newdevelopment-bank\#section-overview

Davidson, P. (2004). The future of the international financial system. Journal of Post Keynesian Economics, 26(4), 591-605.

EBRD. (2020). Investment of Choice. Retrieved from https://www.ebrd.com/investment-ofchoice.pdf

Engen, L., and Prizzon, A. (2018). A guide to multilateral development banks. odi.org. Retrieved from https://cisp.cachefly.net/assets/articles/attachme nts/75082_12274.pdf

ESCAP. (2018). Mobilizing finance for sustained, inclusive and sustainable economic growth. Bangkok: United Nations, ESCAP.

Gabuyev, A. (2015). Taming the dragon. Russia in Global Affairs, (1). Russia in Global Affairs. Retrieved from https://eng.globalaffairs.ru/articles/taming-thedragon/

Guliev, I., Kamalov, R., Rassolova, I., and Arzhaev, F. (2019). The role of AIIB and NDB in the development of the Asian finance. Advances in Social Science, Education and
Humanities Research, volume 332, 23-26. doi: 10.2991/iccesd-19.2019.6

Guttal, S. (2005). The Asian Development Bank: A Problem Institution. Focus on Global South, 9. Retrieved from https://base.socioeco.org/docs/doc-7212_en.pdf Howe, B. M., and Park, M. J. (2017). The evolution of the "ASEAN Way": Embracing human security perspectives. Asia-Pacific Social Science Review, 16(1), 1-15.

Hubner, K., Balik, T., and Deman, A.-S. (2016). CETA: the making of the Comprehensive Economic and Trade Agreement between Canada and the EU. Retrieved from http://www.ifri.org/sites/default/files/atoms/files /notes_ifri_ceta_0.pdf

Ikenberry, G. J., Mastanduno, M., and Wohlforth, W. C. (2009). Unipolarity, State Behavior, and Systemic Consequences. World Politics, 61(1), 1-27. doi: 10.1017/S004388710900001X

IMF. (2019). IMF Financial Activities List. Retrieved from https://www.imf.org/external/createX/createx.as px?series $=\mathrm{fa}$

IMF. (2020). SDR Valuation. Retrieved from https://www.imf.org/external/np/fin/data/rms_sd rv.aspx

Jakupec, V., and Kelly, M. (2015). The relevance of Asian development bank: Existing in the shadow of the Asian infrastructure investment bank. Journal of Regional Socio-Economic Issues, 5(3), 31-46.

James, P., and Patomäki, H. (Eds.). (2007). Globalization and economy (vol. 2: Globalising finance and the new Europe). Los Angeles; London: SAGE.

Jędrzejowska, K. (2020). From Global to Regional Financial Governance? The Case of Asia-Pacific. In M. Rewizorski, K. Jędrzejowska, and A. Wróbel (Eds.), The Future of Global Economic Governance: Challenges and Prospects in the Age of Uncertainty (pp. 103-118). Cham: Springer International Publishing.

Jones, E., \& Knaack, P. (2019). Global Financial Regulation: Shortcomings and Reform Options. Global Policy 10(2), 1-14.

L 11/23. Comprehensive Economic and Trade Agreement (CETA) between Canada and the European Union and its Member States, Official Journal of the European Union, 14 de enero de 2017

Lee, R. (2019). The Top 8 Most Tradable Currencies. Investopedia. Retrieved from https://www.investopedia.com/trading/mosttradable-currencies/ 
Litsareva, E. (2017). Success Factors of AsiaPacific Fast-Developing Regions' Technological Innovation Development and Economic Growth. International Journal of Innovation Studies, 1, pp. 72-88. doi: 10.3724/SP.J.1440.101006

Merics. (2018). China creates a global infrastructure network: Interactive map of the Belt and Road Initiative. Retrieved from https://www.merics.org/en/bri-

tracker/interactive-map

NDB. (2020). Projects. Retrieved from https://www.ndb.int/projects/list-of-all-

projects/page/3/

Ngwu, U. I. (2018). News Flow Challenges in the Present World Information Order: A Critical Analysis. Novena Journal of Commuvication, 5, 182-192.

O'Keeffe, AM, A., Pryke, J., and Wurf, H. (2017). Strengthening the Asian Development Bank in 21st century Asia. Lowy Institute for International Policy. Retrieved from: https://www.lowyinstitute.org/publications/stren gthening-asian-development-bank-21st-centuryasia

Obstfeld, M. (2009). International Finance and Growth in Developing Countries: What Have We Learned? IMF Staff Papers, 56(1), 63-111. doi: 10.1057/imfsp.2008.32

Obstfeld, M., \& Rogof, K. (2009). Global Imbalances and the Financial Crisis: Products of Common Causes. Asia and the Global Financial Crisis. Asia Economic Policy Conference, Santa Barbara, CA, Federal Reserve Bank of San Francisco.

Orastean, R. (2016). Financial globalization global imbalances - global financial crisis. Bulletin of Taras Shevchenko National University of Kyiv Economics, 12(189), 41-44. doi: 10.17721/1728-2667.2016/189-12/7

Ozili, P. K. (2020). Social inclusion and financial inclusion: International evidence. International Journal of Development Issues, 19(2), 169-186. doi: 10.1108/IJDI-07-2019-0122

Prodi, G., and Fardella, E. (2018). The Belt and Road initiative and its impact on Europe (Valdai Papers No. 82). Russia in Global Affairs. Retrieved from https://eng.globalaffairs.ru/articles/the-belt-androad-initiative-and-its-impact-on-europe/

Ray, A., and Dutta, A. (2014). Information Imbalance: A Case Study of Print Media in India. International Journal of Scientific and Research Publications, 4(7). Retrieved from http://www.ijsrp.org/research-paper-0714/ijsrpp3198.pdf

Reuters. (2016). Shanghai Cooperation Organisation to set up bank-Xinhua. Retrieved from https://www.reuters.com/article/china-sco- banks/shanghai-cooperation-organisation-to-setup-bank-xinhua-idUSL4N1D45XI

Riedel, J. (2011). The Slowing Down of Longterm Growth in Asia: Natural Causes, the Middle-Income Trap, and Politics. School of Advanced International Studies, Johns Hopkins University. Retrieved from https://www.researchgate.net/publication/26594 4281

RTAs Database. (2020). RTAs currently in force (by year of entry into force), 1948-2020. Retrieved from http://rtais.wto.org/UI/PublicMaintainRTAHom e.aspx

Saggu, A., and Anukoonwattaka, W. (2015). China's 'New Normal': Challenges Ahead for Asia-Pacific Trade. Trade Insights, (11). Retrieved from https://www.unescap.org/sites/default/files/Trad e-Insights-No11.pdf

Schmidt, R. H., and Hryckiewicz, A. (2006). Financial systems-Importance, differences and convergence (No. 4). Frankfurt am Main: Institute for Monetary and Financial Stability (IMFS), Goethe University. Retrieved from: http://hdl.handle.net/10419/97758

Serra, N., and Stiglitz, J. E. (Eds.). (2008). The Washington Consensus reconsidered: Towards a new global governance. Oxford, New York: Oxford University Press.

Stiglitz, J. E. (2010). The Stiglitz report: Reforming the international monetary and financial systems in the wake of the global crisis. New York: New Press.

Stiglitz, J. E. (2013). The price of inequality. New York: W. W. Norton \& Company.

Stiglitz, J. E., and Gurkaynak, R. S. (Eds.). (2015). Taming capital flows: Capital account management in an era of globalization. Houndmills, Basingstoke, Hampshire. New York, NY: Palgrave Macmillan.

Sung, D. H., \& Uk, H. (2008). U.S. and Japanese Foreign Direct Investment in East Asia: A Comparative Analysis. Policy Studies Journal, 36(3), 385-401. doi: 10.1111/j.15410072.2008.00273.x

Taghizadeh-Hesary, F., Phi, N. T. M., Hong, H. H. T., and Chu, V. T. (2019). Does Financial Integration Matter for Financial Development? Evidence from the East Asian and Pacific Region. Journal of Economic Integration, 34(4), 591-618. doi: 10.11130/jei.2019.34.4.591 Taleb, N. N. (2010). The black swan: The impact of the highly improbable. New York: Random House Trade Paperbacks.

Timmis, H. (2018). The Global Financial System and Developing Countries. Brighton, UK: Institute of Development Studies. 
Veselovsky, M. Ya., Izmailova, M. A., Krasyukova, N. L., Bitkina, I. V., and Gladyshev, A. G. (2017). The effects of financial sector on development of Russian regions under current conditions. Revista Espacios, 38(33), 10. Vinokurov, E., Efimov, A., and Levenkov, A. (2019). The Eurasian Fund for Stabilization and Development: A Regional Financing Arrangement and Its Place in the Global Financial Safety Net (EFSD Working Paper No. WP/19/1). Eurasian Fund for Stabilization and Development. Retrieved from https://efsd.eabr.org/en/research/workingpapers/

World Bank. (2019). Global Financial Development Report 2019/2020: Bank
Regulation and Supervision a Decade after the Global Financial Crisis. The World Bank. doi: 10.1596/978-1-4648-1447-1

World Bank. (2019). Global Financial Development. Retrieved from https://datacatalog.worldbank.org/dataset/global -financial-development

World Bank. (2020). What We Do. Retrieved from https://www.worldbank.org/en/about/whatwe-do

Xu, J., Ren, X., and Wu, X. (2019). Mapping Development Finance Institutions Worldwide: Definitions, Rationales, and Varieties (NSE Development Financing Research Report No. 1). Beijing: Institute of New Structural Economics at Peking University. 